\title{
Physical activity of adolescents in the prevention of lifestyle diseases
}

\author{
Aktywność fizyczna nastolatków w profilaktyce chorób cywilizacyjnych
}

\author{
Anna Bednarek', Anna Bodajko-Grochowska², Danuta Zarzycka', \\ Andrzej Emeryk², Elżbieta Cichosz ${ }^{3}$
}

1Katedra i Zakład Pielęgniarstwa Pediatrycznego, Wydział Nauk o Zdrowiu, Uniwersytet Medyczny w Lublinie/ Chair and Department of Paediatric Nursing, Faculty of Health Sciences, Medical University of Lublin 2Klinika Chorób Płuc i Reumatologii Dziecięcej, Uniwersytecki Szpital Dziecięcy w Lublinie/ Clinic for Lung Diseases and Paediatric Rheumatology, Prof. Antoni Gębala Children's Hospital of Lublin, Medical University of Lublin ${ }^{3}$ Studentka Wydział Nauk o Zdrowiu, Uniwersytet Medyczny w Lublinie/ Student at the Faculty of Health Sciences, Medical University of Lublin

AUTOR DO KORESPONDENCJI/CORRESPONDING AUTHOR:

Anna Bednarek

Katedra i Zakład Pielęgniarstwa Pediatrycznego Wydział Nauk o Zdrowiu, UM w Lublinie

Uniwersytecki Szpital Dziecięcy w Lublinie

ul. Profesora Antoniego Gębali 6, 20-093 Lublin

Tel: +484487740

e-mail: bednarekanna@02.pl

\section{STRESZCZENIE AKIYWNOŚĆ FIZYCZNA NASTOLATKÓW W PROFILAKTYCE CHORÓB CYWILIZACYJNCH}

Wprowadzenie. Aktywność fizyczna nastolatków stanowi ważny element ich prawidłowego rozwoju i prewencji chorób cywilizacyjnych.

Cel pracy. Celem pracy jest ocena aktywności fizycznej nastolatków w profilaktyce chorób cywilizacyjnych.

Materiał i metoda. Badaniami objęto 135 uczniów liceum w Zamościu, w 2016 roku. Zastosowano metodę sondażu diagnostycznego, a narzędzie badawcze stanowił Międzynarodowy Kwestionariusz Aktywności Fizycznej (International Physical Activity Questionnaire IPAQ), w polskiej adaptacji (wersja skrócona) oraz autorski kwestionariusz ankiety.

Wyniki. Ponad połowa ankietowanych $(63,70 \%)$ uprawia sport poza zajęciami wychowania fizycznego w szkole, wybierając najczęściej gry zespołowe. Zgodnie z kluczem dla IPAQ 40,74\% uczniów przejawia wysoką aktywność fizyczną, 39,26\% wystarczającą, a 20\% niewystarczającą. Według uczniów systematyczna aktywność fizyczna ma istotne znaczenie w prewencji cukrzycy $(12,66 \%$ chłopców; 28,57\% dziewcząt, p=0,037). Nie potwierdzono natomiast istotnego jej wpływu na zapobieganie otyłości, chorobom nowotworowym, narządu ruchu czy chorobom układu krążenia.

Wnioski. Większość uczniów deklaruje systematyczną, pozaszkolną aktywność fizyczną. Według oceny IPAQ aktywność fizyczna nastolatków jest na wysokim poziomie, co może stanowić pozytywny wskaźnik dla prewencji chorób cywilizacyjnych.

Słowa kluczowe: aktywność fizyczna, nastolatki, profilaktyka chorób cywilizacyjnych

ABSTRACT

PHYSICAL ACTIVITY OF ADOLESCENTS IN THE PREVENTION OF LIFESTYLE DISEASES

Introduction. The physical activity of adolescents forms an important aspect of their normal development and the prevention of lifestyle diseases.

Aim. The aim of this paper is to evaluate the effect of physical activity of adolescents on the prevention of lifestyle diseases.

Material and method. The study covered a sample of 135 students from a secondary school in Zamość, Poland, was conducted in 2016, and used the diagnostic survey method. The research tool was the International Physical Activity Questionnaire (IPAQ) in its Polish adaptation (the abridged version) and a survey questionnaire developed by the authors.

Results. More than half of the respondents (63.70\%) engaged in sports activities in addition to PE classes at school, usually choosing team sports. According to the IPAQ key, $40.74 \%$ of the students demonstrated a high level of physical activity, $39.26 \%$ a moderate level, and $20 \%$ an insufficient level. The students were of the view that regular physical activity is of substantial importance in the prevention of diabetes ( $12.66 \%$ of the boys; $28.57 \%$ of the girls; $p=0.037$ ). At the same time, it was found not to have any major effect on the prevention of obesity, cancers, diseases of the musculoskeletal system or cardiovascular diseases.

Conclusions. The majority of the students declared that they regularly engaged in physical activity outside of school. According to the IPAQ assessment, the physical activity of adolescents remains at a high level, which may be considered as a positive indicator for the prevention of lifestyle diseases.

Key words: physical activity, adolescents, prevention of lifestyle diseases 


\section{INTRODUCTION}

In its latest recommendations, the WHO (World Health Organisation) stipulates that school-age children perform moderate and high-intensity exercises every day for a period of 60 minutes. The form of physical activity should match the child's stage of development as well as be varied and rewarding for the child $[1,2,3]$.

Lack of exercise contributes to the occurrence of lifestyle diseases (disorders of the cardiovascular and musculoskeletal systems, diabetes, overweight, obesity, cancers). Their first symptoms originate in early childhood, but regular physical activity may act as an effective preventive measure against such disorders $[4,5]$.

\section{AIM}

The aim of this paper is to evaluate the physical activity of adolescents in the prevention of lifestyle diseases (PLD).

\section{MATERIALS AND METHODS}

The study was conducted in 2016 in line with the requirements set out in the Declaration of Helsinki, among the students of a secondary school in Zamość, Poland. The research tool comprised two questionnaires, including the International Physical Activity Questionnaire (IPAQ) in its Polish adaptation by Biernat, Stupnicki, Gajewski [6], and the authors' own survey questionnaire with questions on the physical activity of the students and their awareness of how important this activity is for the prevention of diseases. Statistical calculations were performed using the R 3.1.1 statistical software suite.

The IPAQ questionnaire is designed for the 15-69 age group and covers the period of the last 7 days. It addresses four domains of physical activity: job; transportation; housework, house maintenance, and caring for family; and recreation, sport, and leisure time. For each of these domains, three types of activity are specified (walking, moderate activity, intense activity) and presented with the MET-min./week coefficient, where MET stands for the multiple of one's estimated resting energy expenditure (Metabolic Equivalent of Work); accordingly, walking equals 3.3 MET, moderately intense activity 4 MET and intense activity $-8 \mathrm{MET}$. Weekly physical activity being the sum of the results of each type of physical activity is classified into three levels: high ( $\geq 3$ days of intense effort with $\geq 1500$ MET-min./week or $\geq 7$ days of any combination of efforts with $>3000$ MET-min./week); sufficient $(\geq 3$ days of intense effort lasting $\geq 20 \mathrm{~min}$./day or $\geq 5$ days of moderate effort/walking lasting $\geq 30 \mathrm{~min}$./day or $\geq 5$ days of any combination of efforts with $>600$ MET-min./week); and insufficient (people who do not meet any of the above criteria or do not engage in any form of activity) [6].

In order to assess the nutritional status of adolescents, percentile charts for the Body Mass Index (BMI), developed on the basis of data from the OLAF study, were used. The BMI was calculated on the basis of data from the authors' own survey questionnaire as follows: $\mathrm{BMI}=$ body weight $(\mathrm{kg}) /$ height $^{2}(\mathrm{~m})$. Values between 5 and 85 percentile were used to indicate normal body weight. Body weight is considered to be normal when the BMI falls within the 5-85 percentile range. A patient is declared overweight if the result is $\geq 85-95$ percentile; any value above 95 indicates obesity [7].

\section{RESULTS}

The study (Tab. 1) involved 135 adolescents at an average age of 16.07 years; $58.52 \%$ of them were boys The average body weight of the students was $64.4 \mathrm{~kg}$ $(\mathrm{SD}=15.71$; median - $62 \mathrm{~kg}$ ). Normal body weight was found in $62.22 \%$ of the respondents (BMI in the 5-85 percentile); $3.7 \%$ of them were obese and $8.89 \%$ overweight.

Tab. 1. Characteristics of young people - an analysis of selected demographic and anthropometric features

\begin{tabular}{|l|c|c|}
\hline \multicolumn{1}{|c|}{ Analysed parameters } & N=135 \\
\hline Body weight & \multicolumn{2}{c|}{$64.4(15.71)$} \\
\hline Average weight (SD) & \multicolumn{2}{c|}{$40-102$} \\
\hline Min.-Max.(kg) & \multicolumn{2}{c|}{$15-17$} \\
\hline Me (kg) & \multicolumn{2}{c|}{16.07} \\
\hline Age & n \\
\hline Min.-Max. (years) & \multicolumn{2}{|c|}{$\%$} \\
\hline Arithmetic mean (years) & 79 & 58.52 \\
\hline \multicolumn{1}{|c|}{ Analysed parameters } & 56 & 41.48 \\
\hline Sex & \multicolumn{2}{|c|}{} \\
\hline Boys & 84 & 62.22 \\
\hline Girls & 34 & 21.19 \\
\hline BMI & 12 & 8.89 \\
\hline Standard & 5 & 3.70 \\
\hline Underweight &
\end{tabular}

According to the IPAQ key, $40.74 \%$ of students exhibit a high level, $39.26 \%$ a sufficient level, and $20 \%$ an insufficient level of physical activity (Tab. 2). The majority of the students confirmed that they spent their free time passively with their peers $(57.78 \%)$. The main reason for pursuing sports for $68.15 \%$ of the respondents was due to their being interested in a given form of physical activity.

The importance of regular physical activity in the prevention of diabetes was significantly more frequently reported $(\mathrm{p}=0.037)$ by girls than boys. In the case of other lifestyle diseases, no statistical significance was revealed (Tab. 3). 
Tab. 2. Assessment of the physical activity of students according to the IPAQ questionnaire and the authors' own survey

\begin{tabular}{|c|c|c|}
\hline Analysed parameters & $\mathrm{n}$ & $\%$ \\
\hline \multicolumn{3}{|c|}{ Physical activity of students according to IPAQ } \\
\hline High & 55 & 40.74 \\
\hline Sufficient & 53 & 39.26 \\
\hline Insufficient & 27 & 20.00 \\
\hline Correlation; IPAQ and sex & \multicolumn{2}{|c|}{$p=0.605$} \\
\hline \multicolumn{3}{|c|}{ Willingness to participate in physical education (PE) classes } \\
\hline Yes & 104 & 77.04 \\
\hline No & 31 & 22.96 \\
\hline \multicolumn{3}{|c|}{ Additional physical activity apart from PE classes } \\
\hline Yes* & 86 & 63.70 \\
\hline No & 49 & 36.29 \\
\hline \multicolumn{3}{|c|}{ Manner of spending free time } \\
\hline Sedentary, with peers & 78 & 57.78 \\
\hline Active, with peers & 57 & 42.22 \\
\hline \multicolumn{3}{|c|}{ Motivation factor for adolescents to do sports } \\
\hline I'm fascinated by sport & 92 & 68.15 \\
\hline
\end{tabular}

*3-7 times a week; usually team sports

Tab. 3 Assessment of the effect of regular physical activity among adolescents on PLD

\begin{tabular}{|l|c|c|}
\hline \multicolumn{1}{|c|}{ Analysed parameters } & $\mathbf{n}$ & $\%$ \\
\hline \multicolumn{2}{|c|}{$\begin{array}{c}\text { Regular physical activity in the prevention of musculoskeletal } \\
\text { system diseases }\end{array}$} \\
\hline Boys & 74 & $93.67^{*}$ \\
\hline Girls & 49 & $87.50^{*}$ \\
\hline$p=0.35$ & \\
\hline
\end{tabular}

Regular physical activity in the prevention of cardiovascular diseases

\begin{tabular}{|l|l|l|}
\hline Boys & 40 & $50.63^{*}$ \\
\hline Girls & 24 & $42.86^{*}$ \\
\hline
\end{tabular}

$\mathrm{p}=0.474$

Regular physical activity in the prevention of obesity

\begin{tabular}{|l|c|c|}
\hline Boys & 33 & $41.77^{*}$ \\
\hline Girls & 30 & $53.57^{*}$ \\
\hline$p=0.238$ &
\end{tabular}

$p=0.238$

\begin{tabular}{|l|c|c|}
\hline \multicolumn{3}{|c|}{ Regular physical activity in the prevention of diabetes } \\
\hline Boys & 10 & $12.66^{*}$ \\
\hline Girls & 16 & $28.57^{*}$ \\
\hline
\end{tabular}

$p=0.037$

\begin{tabular}{|l|c|c|}
\hline \multicolumn{3}{|c|}{ Regular physical activity in the prevention of cancer } \\
\hline Boys & 6 & $7.59^{*}$ \\
\hline Girls & 8 & $14.29^{*}$ \\
\hline $\mathrm{p}=0.332$ & & \\
\hline
\end{tabular}

*the percentages do not add up to $100 \%$ because this is a multiple choice question (various factors contributing to the prevention of lifestyle diseases)

\section{DISCUSSION}

Lacking in physical activity, modern societies' lifestyles have an adverse impact on health, the negative consequences of which are evident particularly during adolescence. Teenagers vary considerably in their awareness of how important physical activity is for health, and the level of their behaviours conducive to various forms of physical activity is often unsatisfactory, both in Poland and in other European countries and Western cultures. Furthermore, many studies reveal a drop in the levels of physical activity in the period from early adolescence to adulthood, especially among girls $[2,8]$.

While a significant percentage of children and adolescents still choose to rest passively in front of a computer or television, symptoms of changes in the approach to active lifestyle have now been observed among young people from various cultural backgrounds [3, 4].

According to Polish authors, $70 \%$ of children aged 6-7 years exhibit an appropriate level of physical activity in terms of its frequency and intensity; however, over the adolescent years, active forms of leisure tend to give way to sedentary forms of activity. Consequently, every fourth eleven-year-old and every tenth seventeen-year-old does not meet the WHO requirements as regards daily levels of physical activity $[8,9]$.

On the basis of the authors' own research carried out with the use of the IPAQ questionnaire, it was indicated that physical activity of over $80 \%$ of the respondents is at a good level. This constitutes a favourable prognostic factor as regards the prevention of diseases attributable to the poor level of physical activity. In addition, more than half of young people have a correct BMI. Furthermore, in the study by Grabińska et al. [10] among 268 lower secondary students, a large portion of the respondents considered their levels of physical activity as very high ( $29 \%$ of the girls and $51 \%$ of the boys).

The respondents viewed regular physical activity as the most important lifestyle factor which for them was conducive to the prevention of diabetes $(28.57 \%$ of the girls and $12.66 \%$ of the boys, $\mathrm{p}=0.037$ ). According to data in the literature, physical activity not only helps maintain normal body weight, but also reduces tissue insulin resistance [11]. On the other hand, in the study by Owoc et al. [12] conducted among secondary school students, almost half of the respondents $(47.41 \%)$ stated that physical activity plays the central role in the prevention of arterial hypertension and atherosclerosis. The results of the authors' own research have not indicated any significance in this respect.

Cancer is an important contributor to morbidity and mortality in developing countries as well as in Poland. Frequent exercise has been shown to reduce the risk of colorectal, breast, prostate and endometrial cancers [1]. In authors' own research, few students reported regular physical activity as important in the prevention of cancer (around $14 \%$ of girls and slightly over $7 \%$ of boys). Similarly, in the study by Dziubak et al. [5], the low level of physical activity, as one of cancer risk factors, was listed by the least number of secondary school students (33.6\%). 
In authors' own research, more than half of the respondents $(63.70 \%)$ did sports in addition to PE classes at school, usually choosing team sports. Similar results were obtained by Marcysiak et al. [13] among primary and lower secondary school students - she found that $88 \%$ of the students regularly engaged in and generally preferred team sports (27\% of the students). According to Nawrocka et al. [14], 52\% of lower secondary school students take up physical activity every day and $48 \%$ of them do sports 2-3 times a week.

\section{CONCLUSIONS}

1. The majority of the students declared that they regularly engaged in physical activity outside of school.

2. According to the IPAQ assessment, the physical activity of adolescents remains at a high level, which may be considered as a positive indicator for the prevention of lifestyle diseases.

\section{Aktywność fizyczna nastolatków w profilaktyce chorób cywilizacyjnych}

\section{WPROWADZENIE}

Najnowsze rekomendacje WHO (World Health Organization) zalecają, aby dzieci w wieku szkolnym wykonywały codzienne ćwiczenia o umiarkowanej i dużej intensywności przez 60 minut. Forma aktywności powinna być dostosowana do ich etapu rozwoju, urozmaicona oraz stanowiąca źródło satysfakcji $[1,2,3]$.

Niedostatek ruchu przyczynia się do występowania chorób cywilizacyjnych (schorzenia układu sercowo-naczyniowego i układu ruchu, cukrzyca, nadwaga, otyłość, choroby nowotworowe). Ich rozwój ma swoje początki już we wczesnym dzieciństwie, a systematyczna aktywność fizyczna stanowi prewencję tych zaburzeń $[4,5]$.

\section{CEL PRACY}

Celem pracy jest ocena aktywności fizycznej nastolatków w profilaktyce chorób cywilizacyjnych (PCHC).

\section{MATERIAŁ I METODA}

Badanie przeprowadzono zgodnie z wymogami Deklaracji Helsińkiej w 2016 roku, wśród uczniów liceum z Zamościa. Narzędzie badawcze stanowiły dwa kwestionariusze, w tym Międzynarodowy Kwestionariusz Aktywności Fizycznej - IPAQ, w polskiej adaptacji przez Biernat, Stupnicki, Gajewski [6] oraz kwestionariusz ankiety własnej, który zawierał pytania o aktywność ruchową uczniów i wiedzę młodzieży na temat znaczenia aktywności fizycznej w profilaktyce chorób. Obliczenia statystyczne wykonano za pomocą programu pakietu statystycznego R 3.1.1.

Kwestionariusz IPAQ przeznaczony jest dla osób w wieku 15-69 lat i odnosi się do okresu ostatnich 7 dni. Zawiera on cztery domeny aktywności fizycznej, tj. pracę zawodową, przemieszczanie się z miejsca na miejsce, prace domowe oraz udział $w$ sporcie i rekreacji w czasie wolnym. Dla każdego z wymienionych obszarów określa się trzy rodzaje aktywności (chodzenie, umiarkowana, intensywna), przedstawiając je przy użyciu współczynnika MET-min./tydzień, gdzie MET odpowiada wielokrotności przemiany podstawowej (Metabolic Equivalent of Work - MET) i dla chodzenia wynosi 3,3 MET, dla umiarkowanej aktywności 4 MET oraz intensywnej - 8 MET. Tygodniowa aktywność fizyczna będąca sumą wyników każdego rodzaju aktywności fizycznej klasyfikowana jest do trzech poziomów: wysokiego ( $\geq 3 \mathrm{dni}$ intensywnych wysiłków $\mathrm{z} \geq 1500$ MET-min./tydzień lub $\geq 7 \mathrm{dni}$ którejkolwiek kombinacji wysiłków z > 3000 MET-min./ tydzień), wystarczającego ( $\geq 3$ dni intensywnych wysiłków trwających $\geq 20 \mathrm{~min}$./dzień lub $\geq 5$ dni umiarkowanych wysiłków/chodzenia trwających $\geq 30 \mathrm{~min}$./dzień lub $\geq 5$ dni którejkolwiek kombinacji wysiłków z > 600 MET-min./tydzień) oraz niewystarczającego (osoby niespełniające żadnego z powyższych kryteriów lub niewykazujące żadnej aktywności) [6].

Do oceny stanu odżywienia nastolatków użyto siatek centylowych Wskaźnika Masy Ciała (Body Mass Index - BMI) opracowanych na podstawie danych z badania OLAF. Współczynnik BMI został obliczony w oparciu o dane uzyskane $\mathrm{z}$ kwestionariusza ankiety własnej zgodnie ze wzorem: $\mathrm{BMI}=$ masa ciała $(\mathrm{kg}) /$ wzrost $^{2}(\mathrm{~m})$. Za prawidłową masę ciała przyjęto wartości pomiędzy 5 a 85 centylem. Prawidłową masę ciała stwierdza się, gdy wskaźnik BMI mieści się w zakresie pomiędzy 5 a 85 centylem. O nadwadze u pacjenta świadczy wynik $\geq 85-95$ centyl, a powyżej 95 centyla wskazuje na otyłość [7].

\section{WYNIKI}

W badaniach (tab. 1) wzięło udział 135 nastolatków ze średnią wieku 16,07 lat, z czego 58,52\% stanowili chłopcy. Średnia masa ciała uczniów wyniosła $64,4 \mathrm{~kg}(\mathrm{SD}=15,71$; mediana - $62 \mathrm{~kg}$ ). Prawidłową masę ciała miało $62,22 \%$ nastolatków (wskaźnik BMI 5-85 centyl), 3,7\% było otyłych, a u 8,89\% występowała nadwaga. 
Tab. 1. Charakterystyka młodzieży - analiza wybranych cech demograficznych i antropometrycznych

\begin{tabular}{|c|c|c|}
\hline Analizowane parametry & \multicolumn{2}{|c|}{$\mathrm{N}=135$} \\
\hline \multicolumn{3}{|l|}{ Masa ciała } \\
\hline Średnia masa (SD) & \multicolumn{2}{|c|}{$64,4(15,71)$} \\
\hline Min.-Max.(kg) & \multicolumn{2}{|c|}{$40-102$} \\
\hline $\mathrm{Me}(\mathrm{kg})$ & \multicolumn{2}{|c|}{62} \\
\hline \multicolumn{3}{|l|}{ Wiek } \\
\hline Min.-Max. (lata) & \multicolumn{2}{|c|}{$15-17$} \\
\hline Średnia art. (lata) & \multicolumn{2}{|c|}{16,07} \\
\hline Analizowane parametry & $\mathbf{n}$ & $\%$ \\
\hline \multicolumn{3}{|l|}{ Płeć } \\
\hline Chłopcy & 79 & 58,52 \\
\hline Dziewczęta & 56 & 41,48 \\
\hline \multicolumn{3}{|l|}{ BMI } \\
\hline Norma & 84 & 62,22 \\
\hline Niedowaga & 34 & 21,19 \\
\hline Nadwaga & 12 & 8,89 \\
\hline Otyłość & 5 & 3,70 \\
\hline
\end{tabular}

Zgodnie z kluczem dla IPAQ 40,74\% uczniów przejawia wysoką aktywność fizyczną, 39,26\% wystarczającą aktywność, a 20\% niewystarczającą aktywność (tab. 2). Większość uczniów potwierdza bierny sposób spędzania wolnego czasu z rówieśnikami (57,78\%). Głównym powodem uprawiania sportu dla $68,15 \%$ ankietowanych jest fascynacja określoną formą aktywności ruchowej.

Znaczenie systematycznej aktywności fizycznej w profilaktyce cukrzycy istotnie częściej $(\mathrm{p}=0,037)$ wymieniają dziewczęta, niż chłopcy. W przypadku pozostałych chorób cywilizacyjnych nie wykazano istotności statystycznej (tab. 3).

Tab. 2. Ocena aktywności fizycznej uczniów wg kwestionariusza IPAQ i ankiety własnej

\begin{tabular}{|c|c|c|}
\hline Analizowane parametry & $\mathbf{n}$ & $\%$ \\
\hline \multicolumn{3}{|c|}{ Aktywność fizyczna uczniów wg IPAQ } \\
\hline Wysoka aktywność & 55 & 40,74 \\
\hline Wystarczająca aktywność & 53 & 39,26 \\
\hline Niewystarczająca aktywność & 27 & 20,00 \\
\hline Zależność; IPAQ a płeć & \multicolumn{2}{|c|}{$p=0,605$} \\
\hline \multicolumn{3}{|c|}{ Chęć uczestnictwa w zajęciach wychowania fizycznego (WF) } \\
\hline Tak & 104 & 77,04 \\
\hline Nie & 31 & 22,96 \\
\hline \multicolumn{3}{|c|}{ Dodatkowa aktywność fizyczna poza zajęciami WF } \\
\hline Tak $^{*}$ & 86 & 63,70 \\
\hline Nie & 49 & 36,29 \\
\hline \multicolumn{3}{|c|}{ Sposób spędzania czasu wolnego } \\
\hline Sedenteryjnie, z rówieśnikami & 78 & 57,78 \\
\hline Aktywnie, z rówieśnikami & 57 & 42,22 \\
\hline \multicolumn{3}{|c|}{ Czynnik motywacyjny uprawiania sportu przez młodzież } \\
\hline Fascynuje mnie sport & 92 & 68,15 \\
\hline
\end{tabular}

*3-7 razy w tygodniu; najczęściej gry zespołowe
Tab. 3 Ocena wpływ systematycznej aktywności fizycznej młodzieży na $\mathrm{PCHC}$

\begin{tabular}{|c|c|c|}
\hline Analizowane parametry & $\mathbf{n}$ & $\%$ \\
\hline \multicolumn{3}{|c|}{ Systematyczna aktywność fizyczna w profilaktyce chorób narządu ruchu } \\
\hline Chłopcy & 74 & $93,67^{*}$ \\
\hline Dziewczęta & 49 & $87,50^{*}$ \\
\hline \multicolumn{3}{|l|}{$\mathrm{p}=0,35$} \\
\hline \multicolumn{3}{|c|}{ Systematyczna aktywność fizyczna w profilaktyce chorób układu krążenia } \\
\hline Chłopcy & 40 & $50,63^{*}$ \\
\hline Dziewczęta & 24 & $42,86^{*}$ \\
\hline \multicolumn{3}{|l|}{$p=0,474$} \\
\hline \multicolumn{3}{|c|}{ Systematyczna aktywność fizyczna w profilaktyce otyłości } \\
\hline Chłopcy & 33 & $41,77^{*}$ \\
\hline Dziewczęta & 30 & $53,57^{*}$ \\
\hline \multicolumn{3}{|l|}{$p=0,238$} \\
\hline \multicolumn{3}{|c|}{ Systematyczna aktywność fizyczna w profilaktyce cukrzycy } \\
\hline Chłopcy & 10 & $12,66^{*}$ \\
\hline Dziewczęta & 16 & $28,57^{*}$ \\
\hline \multicolumn{3}{|l|}{$\mathrm{p}=0,037$} \\
\hline \multicolumn{3}{|c|}{$\begin{array}{l}\text { Systematyczna aktywność fizyczna w profilaktyce chorób } \\
\text { nowotworowych }\end{array}$} \\
\hline Chłopcy & 6 & $7,59^{*}$ \\
\hline Dziewczęta & 8 & $14,29 *$ \\
\hline $\mathrm{p}=0,332$ & & \\
\hline
\end{tabular}

*odsetki nie sumują się do $100 \%$, ponieważ było to pytanie wielokrotnego wyboru (udział różnych czynników w profilaktyce chorób cywilizacyjnych)

\section{DYSKUSJA}

Mało aktywny tryb życia współczesnych społeczeństw powoduje negatywne skutki zdrowotne, których konsekwencje są szczególnie niekorzystne w okresie młodzieńczym. Stan świadomości nastolatków na temat znaczenia aktywności ruchowej dla zdrowia jest bardzo zróżnicowany, a poziom ich zachowań sprzyjających różnym formom aktywności fizycznej dość często niezadawalający, zarówno w Polsce, jak i w innych krajach europejskich oraz kulturach zachodnich. Wiele badań wskazuje również na spadek aktywności fizycznej w okresie od wczesnego wieku dojrzewania do dorosłości, szczególnie u dziewcząt $[2,8]$.

Mimo, iż wciąż znaczący odsetek dzieci i młodzieży odpoczywa biernie przed komputerem lub telewizorem to w kręgach młodych ludzi różnych kulturowo społeczeństw dostrzega się obecnie także symptomy zmian w podejściu do aktywnego stylu życia [3, 4].

$\mathrm{Z}$ doniesień autorów polskich wynika, że prawidłową aktywność fizyczną pod względem jej częstości i intensywności ma 70\% dzieci w wieku 6-7 lat, a przez kolejne lata dorastania, aktywny wypoczynek obniża się na korzyść sedenteryjnych form spędzania czasu wolnego, dlatego co czwarty jedenastolatek oraz co dziesiąty siedemnastolatek nie spełnia wymagań WHO dotyczących codziennej aktywności fizycznej $[8,9]$.

Na podstawie badań własnych przeprowadzonych przy pomocy kwestionariusza IPAQ wykazano, że aktywność fizyczna ponad $80 \%$ respondentów jest na dobrym 
poziomie, co stanowi pomyślny wskaźnik prognostyczny $\mathrm{w}$ zapobieganiu chorobom $\mathrm{z}$ niedostatku ruchu. Ponadto przeszło połowa młodzieży ma prawidłowy wskaźnik BMI. Również według badań Grabińskiej wsp. [10] przeprowadzonych wśród 268 uczniów gimnazjum, znaczna część respondentów uważała własną aktywność fizyczną za bardzo dużą (29\% dziewcząt i 51\% chłopców).

W opinii respondentów najistotniejszym czynnikiem stylu życia była systematyczna aktywność fizyczna, mająca wpływ na profilaktykę cukrzycy $(28,57$ \% dziewcząt i 12,66 \% chłopców, p=0,037). Zgodnie z danymi z piśmiennictwa aktywność fizyczna nie tylko pomaga w utrzymaniu prawidłowej masy ciała, ale również zmniejsza insulinooporność tkanek [11]. Z kolei w badaniach Owoc i wsp. [12] przeprowadzonych wśród uczniów szkół średnich, prawie połowa ankietowanych $(47,41 \%)$ stwierdziła, że aktywność fizyczna odgrywa największą rolę $\mathrm{w}$ profilaktyce nadciśnienia tętniczego i miażdżycy. Wyniki własne nie wskazują istotności w tym zakresie.

Choroby nowotworowe są istotną przyczyną chorobowości i śmiertelności w krajach rozwijających się, jak również w Polsce. Wykazano, że częsty ruch zmniejsza ryzyko raka jelita grubego, piersi, gruczołu krokowego i endometrium [1]. W badaniach własnych niewiele uczniów zaznaczyło systematyczną aktywność fizyczną jako istotną w profilaktyce chorób nowotworowych (około 14\% dziewcząt i nieco ponad 7\% chłopców). Podobnie w badaniach Dziubak i wsp. [5] najmniej młodzieży licealnej (33,6\%) wśród czynników ryzyka chorób nowotworowych wymieniło niską aktywność ruchową.

$\mathrm{W}$ badaniach własnych ponad połowa ankietowanych $(63,70 \%)$ uprawia sport dodatkowo, poza zajęciami WF w szkole, wybierając najczęściej gry zespołowe. Podobne wyniki uzyskała Marcysiak i wsp. [13] wśród młodzieży szkół podstawowych oraz gimnazjalnych, które pokazują, że $88 \%$ uczniów regularnie ćwiczy i najczęściej preferuje gry zespołowe (27\% uczniów). Z kolei według Nawrockiej i wsp. [14] 52\% gimnazjalistów podejmuje aktywność fizyczną codziennie, a $48 \% \mathrm{z}$ nich uprawia sport 2-3 razy w tygodniu.

\section{WNIOSKI}

1. Większość uczniów deklaruje systematyczną, pozaszkolną aktywność fizyczną.

2. Według oceny IPAQ aktywność fizyczna nastolatków jest na wysokim poziomie, co może stanowić pozytywny wskaźnik dla prewencji chorób cywilizacyjnych.

\section{PIŚMIENNICTWO/REFERENCES}

1. Ponczek D, Olszowy I. Styl życia młodzieży i jego wpływ na zdrowie. Probl. Hig. Epidemiol. 2012; 2 (93): 260-268.

2. Althoff T, Sosič R, Hicks JL, et al. Large-scale physical activity data reveal worldwide activity inequality. Nature; 2017; doi:10.1038/nature23018

3. Mazur J, Małkowska-Szkutnik A. red. Wyniki badań HBSC 2010. Raport Techniczny. Warszawa: Instytut Matki i Dziecka; 2011: 109-121.

4. Brzeźniak H, Mroczek B, Kotwas A, i wsp. Analiza wybranych zachowań zdrowotnych oraz samooceny masy ciała szczecińskich gimnazjalistów. Fam. Med. Prim. Care Rev. 2015;17 (2): 82-85.

5. Dziubak M, Dziedzic M, Mierzwa A. Wiedza licealistów o wpływie stylu życia na występowanie chorób układu krążenia i chorób nowotworowych a ich zachowania zdrowotne. Prz. Med. Uniwer. Rzesz. Inst. Leków w Warszawie. 2011; 2: 224-238.

6. Biernat E, Stupnicki R, Gajewski AK. Międzynarodowy Kwestionariusz Aktywności Fizycznej (IPAQ) - wersja polska. Wychow. Fiz. i Sport 2007; 51 (1): 47-54.

7. Kułaga Z, Różdżyńska A, Palczewska I, i wsp. Siatki centylowe wysokości, masy ciała i wskaźnika masy ciała dzieci i młodzieży w Polsce - wyniki badania OLAF. Stand. Med. Pediatr. 2010; 7: 690-700.

8. Currie C, Zanotti C, Morgan A, et al. Social determinants of health and well-being among young people. Health Behaviour in School-Aged Children (HBSC) Study: international report from the 2009/2010 survey. Copenhagen: WHO Regional Office for Europe, 2012.

9. Wojtyła A, Biliński P, Bojar I, Wojtyła K. Aktywność fizyczna młodzieży gimnazjalnej w Polsce. Probl. Hig. Epidemiol. 2011; 2 (92): 335-342.

10. Grabińska M, Barczykowska $E$, Bordon $M$, i wsp. Wybrane aspekty stylu życia młodzieży gimnazjalnej. J. Health Sci. 2014; 4 (11): 309-327.

11. Owoc A, Maliszewska D, Bojar I. Ocena poziomu wiedzy młodzieży warszawskich szkółśrednich na temat wybranych czynników ryzyka chorób układu krążenia. Med. 0g. 2010; 45 (16): 582-594.

12. Marcysiak M, Zagroba M, Ostrowska B, i wsp. Aktywność fizyczna a zachowania żywieniowe dzieci i młodzieży powiatu ciechanowskiego. Probl. Pielęg. 2010; 18 (2): 176-183.

13. Nawrocka M, Kujawska-Łuczak M, Bogdański P, i wsp. Ocena sposobu odżywiania i aktywności fizycznej wśród uczniów szkół ponadpodstawowych. Endokr. Otyłość i Zab. Przem. Mat. 2010; 6 (1): 8-17.

Praca zgłoszona do czasopisma/Manuscript received: 30.07.2018

Praca zaakceptowana do druku/Manuscript accepted: 27.09.2018

Tłumaczenie/Translation: Marek Majcher 